\title{
IN VITRO CYTOTOXIC ACTIVITY OF SECOISOLARICIRESINOL DIGLUCOSIDE ON HT-29, PA-1 CELL LINES, AND $\alpha$-AMYLASE INHIBITORY ACTIVITY
}

\author{
GUNABHUSHANA DADDALA*, SWAROOPARANI A
}

Department of Biotechnology, Jawaharlal Nehru Technological University, Ananthapur, Andhra Pradesh, India. Email: daddala.gunabhushana@gmail.com

Received: 19 November 2019, Revised and Accepted: 30 December 2019

\section{ABSTRACT}

Objective: The present study was conducted to evaluate the in vitro cytotoxic activity and $\alpha$ - amylase inhibitory activity of secoisolariciresinol diglucoside (SDG).

Methods: The cytotoxic activity was conducted on HT-29 (human colon cancer cell line) and PA-1 (human ovarian cancer cell line) by 3-(4,5-dimethylthiazol-2-yl)-2,5-diphenyl tetrazolium bromide assay and the $\alpha$ - amylase inhibitory activity using acarbose as a standard. Both the tests were evaluated at different concentrations, 3.125-100 $\mu \mathrm{g} / \mathrm{ml}$ and 50-2000 $\mu$ g correspondingly and the concentration required for a 50\% inhibition of viability $\left(\mathrm{IC}_{50}\right)$ was determined graphically. The effect of the samples on the proliferation of HT-29 and PA-1 was expressed as the percentage cell viability.

Results: SDG exhibited a considerable dose- and time-dependent inhibition on both HT-29 and PA-1 and also observed a concentration-dependent $\alpha$-amylase inhibitory activity that leads in reduction of starch hydrolysis and hence eventually to lowered glucose levels.

Conclusion: The present in vitro study concluded that SDG can be a potent anticancer and moderate hyperglycemic component.

Keywords: Secoisolariciresinol diglucoside, HT-29 cell lines, PA-1 cell lines, $\alpha$-amylase inhibition.

(C) 2020 The Authors. Published by Innovare Academic Sciences Pvt Ltd. This is an open access article under the CC BY license (http://creativecommons. org/licenses/by/4. 0/) DOI: http://dx.doi.org/10.22159/ajpcr.2020.v13i2.36414

\section{INTRODUCTION}

Cancer is a communal health problem all over the world which may affect many different parts of the body. If the process is not controlled, it could progress until it causes the death of the organism [1]. Plants are the source of medicine from thousands of years and phytochemicals are continued to play an essential role in medicine. The use of medicinal plant extracts for the treatment of human diseases is an ancient practice; this has greatly increased in recent years. For a long time, plants are being used in the treatment of cancer [2]. Usage of medicinal plants for infection as curative by man is an old practice. In the past time, man searches for drugs from different sources such as preserved monuments, writer documents, and from plants [3]. Since early times, plants were playing an important and key role in food and drug administration [4]. Medicinal plants are considered as a healthy source of human life due to their therapeutical capacities in the treatment of different diseases [5].

Natural products and its related drugs are used to treat about $87 \%$ of all categorized human diseases including bacterial infections, cancer, and immunological disorders [6]. About 25\% of prescribed drugs in the world originate from plants [7] and over 3000 species of plants have been reported to have anticancer properties [8]. About $80 \%$ of the populations in developing countries rely on traditional plant-based medicines for their primary health-care needs [9]. Natural products possess immense pharmacological significance in the development of drugs and were discovered through plant bioprospecting. Majority of the drugs, such as paclitaxel, etoposide, camptothecin, vinca alkaloids, indole alkaloids, podophyllotoxin derivatives, etoposide, and teniposide, at present used in clinical cancer chemotherapy, were originally derived from plants [10].

Phytochemicals with various bioactivities including antioxidant, anti-inflammatory, and anticancer properties are extensively extracted from many plant species. To date, the potential of using novel bioactive plant extracts for cancer prevention is still dominating over synthetic chemicals present in drug production [11-13]. Numerous studies indicated that in many types of cancer cells, dietary agents would induce apoptosis and cell cycle arrest without affecting the normal cells $[14,15]$. Pharmacological research on the medicinal properties of phytochemicals has become mandatory, to establish the claimed medicinal properties of herbs [16]. The World Health Organization estimated that about $80 \%$ of the populations in developing countries rely on traditional medicines, mostly plant drugs, for their primary health-care needs $[17,18]$.

Secoisolariciresinol diglucoside (SDG) is the major lignin found in Linum usitatissimum [19], a range of studies on SDG supported its antioxidant [20,21] and anticancer [22] properties. Mammalian lignans show structural similarities to estradiol [23]. Experimental studies have been shown that flaxseed and SDG are shown to be protective against azoxymethane-induced colon carcinogenesis in rats [24,25]. Aberrant crypt foci (ACF) of the colon are possible precursors of adenoma and cancer and were described as lesions consisting of large, thick crypts in methylene blue-stained specimens of colon from mice treated with a carcinogen [26]

In animals, $\alpha$-amylase inhibitors drop the high glucose levels that can occur post-meal by decelerating the speed with which $\alpha$-amylase can transform starch to simple sugars [27]. $\alpha$-Amylase inhibitors offer an effective strategy to lower the levels of slowing the speed with which $\alpha$-amylase can convert starch to simple sugars until the body can deal with it. This is of particular importance in those with diabetes, where low insulin levels prevent extracellular glucose from being cleared quickly from the blood. The finest approach for controlling postprandial hyperglycemia is to reduce the carbohydrate hydrolyzing enzymes such as $\alpha$ - amylase and $\alpha$-glucosidase in the digestive system [28]. 
However, this in vitro study outlines the cytotoxic activity of the SDG against HT-29 and PA-1 cell lines since both cell lines were not studied much and also not much data have been available. The $50 \%$ inhibitory concentration $\left(\mathrm{IC}_{50}\right)$ was calculated and represented, also evaluated the $\alpha$-amylase inhibitory activity of SDG.

\section{METHODS}

3-(4,5-dimethylthiazol-2-yl)-2,5-diphenyl tetrazolium bromide (MTT) reagent, dimethyl sulfoxide (DMSO), carbon dioxide $\left(\mathrm{CO}_{2}\right)$ incubator, and Spectrostar Nano enzyme-linked immunosorbent assay (ELISA) microplate reader were used. Dulbecco's Modified Eagle Medium, fetal bovine serum (FBS), Pen strip, Trypsin procured from Invitrogen, $\alpha$-amylase purchased from Loba, starch, dinitrosalicylic acid, $\mathrm{Na}_{2} \mathrm{SO}_{3}$, and $\mathrm{NaOH}$ used were obtained from Sisco Research Laboratories, SDG isolated from flaxseed [29].

\section{Cell lines and culture medium}

HT-29 (human colon cancer cell line) was procured from ATCC, human ovarian teratocarcinoma cell lines (PA-1) were procured from NCCS, stock cells were cultured in medium supplemented with $10 \%$ inactivated FBS, penicillin (100 IU/ml), and streptomycin $(100 \mu \mathrm{g} / \mathrm{ml})$ in an humidified atmosphere of $5 \% \mathrm{CO}_{2}$ at $37^{\circ} \mathrm{C}$ until confluent. The cells were dissociated with Trypsin Phosphate Versene Glucose solution ( $0.2 \%$ trypsin, $0.02 \%$ ethylenediaminetetraacetic acid, and $0.05 \%$ glucose in phosphate buffer saline [PBS]). The cell viability was checked and centrifuged. Further, 50,000 cells/well of Jurkat were seeded in a 96-well microtiter plate and incubated for $24 \mathrm{~h}, 48 \mathrm{~h}$, and $72 \mathrm{~h}$ at $37^{\circ} \mathrm{C}, 5 \% \mathrm{CO}_{2}$ incubator.

\section{Preparation of test solutions for cytotoxic study}

A $3-100 \mu \mathrm{g} / \mathrm{ml}$ of serial dilutions of SDG were prepared to carry out cytotoxic studies.

\section{Cytotoxic study by MTT assay}

Cytotoxicity of the SDG on HT-29 cells and PA-1 cells was evaluated by studying the cell viability by MTT assay [30,31]. The monolayer cell culture was trypsinized and the cell count was adjusted to $1.0 \times 10^{5}$ cells $/ \mathrm{ml}$ using the media containing $10 \%$ FBS. Added $100 \mu \mathrm{L}$ of the diluted cell suspension (50,000 cells/well) to each well of the 96-well microtiter plates. After $24 \mathrm{~h}$ of incubation, when a partial monolayer was formed, the supernatant was flipped off. The monolayer was washed with medium once and $100 \mu \mathrm{L}$ of different test concentrations of $3.125 \mu \mathrm{g} / \mathrm{ml}, 6.25 \mu \mathrm{g} / \mathrm{ml}, 9.5 \mu \mathrm{g} / \mathrm{ml}, 25 \mu \mathrm{g} / \mathrm{ml}, 50 \mu \mathrm{g} / \mathrm{ml}$, and

Table 1: In vitro cytotoxicity of secoisolariciresinol diglucoside on HT-29 cell line

\begin{tabular}{|c|c|c|c|c|c|c|}
\hline \multirow{2}{*}{$\begin{array}{l}\text { Concentration } \\
(\mu \mathrm{g} / \mathrm{ml})\end{array}$} & \multicolumn{3}{|c|}{$\%$ cell viability (mean) } & \multicolumn{3}{|l|}{$\mathrm{IC}_{50}$} \\
\hline & $24 \mathrm{~h}$ & $48 \mathrm{~h}$ & $72 \mathrm{~h}$ & $24 \mathrm{~h}$ & $48 h$ & $72 \mathrm{~h}$ \\
\hline 3.125 & 95.55 & 97.43 & 96.51 & & & \\
\hline 6.25 & 93.55 & 94.60 & 94.49 & & & \\
\hline 12.5 & 90.45 & 88.52 & 84.67 & $>100$ & $>100$ & 75.58 \\
\hline 25 & 88.47 & 82.10 & 71.79 & & & \\
\hline 50 & 82.83 & 71.20 & 53.07 & & & \\
\hline 100 & 70.62 & 50.40 & 43.70 & & & \\
\hline
\end{tabular}

Cell viability percentage is presented as mean of triplicate

Table 2: In vitro cytotoxicity of secoisolariciresinol diglucoside on $\mathrm{PA}-1$ cell line

\begin{tabular}{|c|c|c|c|c|c|c|}
\hline \multirow{2}{*}{$\begin{array}{l}\text { Concentration } \\
(\mu \mathrm{g} / \mathrm{ml})\end{array}$} & \multicolumn{3}{|c|}{$\%$ cell viability (mean) } & \multicolumn{3}{|l|}{$\mathrm{IC}_{50}$} \\
\hline & $24 \mathrm{~h}$ & $48 h$ & $72 \mathrm{~h}$ & $24 \mathrm{~h}$ & $48 h$ & $72 \mathrm{~h}$ \\
\hline 3.125 & 97.52 & 92.08 & 90.34 & & & \\
\hline 6.25 & 86.56 & 83.86 & 79.94 & & & \\
\hline 12.5 & 79.33 & 75.73 & 70.58 & 112.70 & 72.69 & 57.49 \\
\hline 25 & 73.12 & 69.59 & 65.78 & & & \\
\hline 50 & 58.54 & 52.71 & 49.97 & & & \\
\hline 100 & 51.59 & 44.38 & 41.77 & & & \\
\hline
\end{tabular}

Cell viability percentage is presented as mean of triplicate

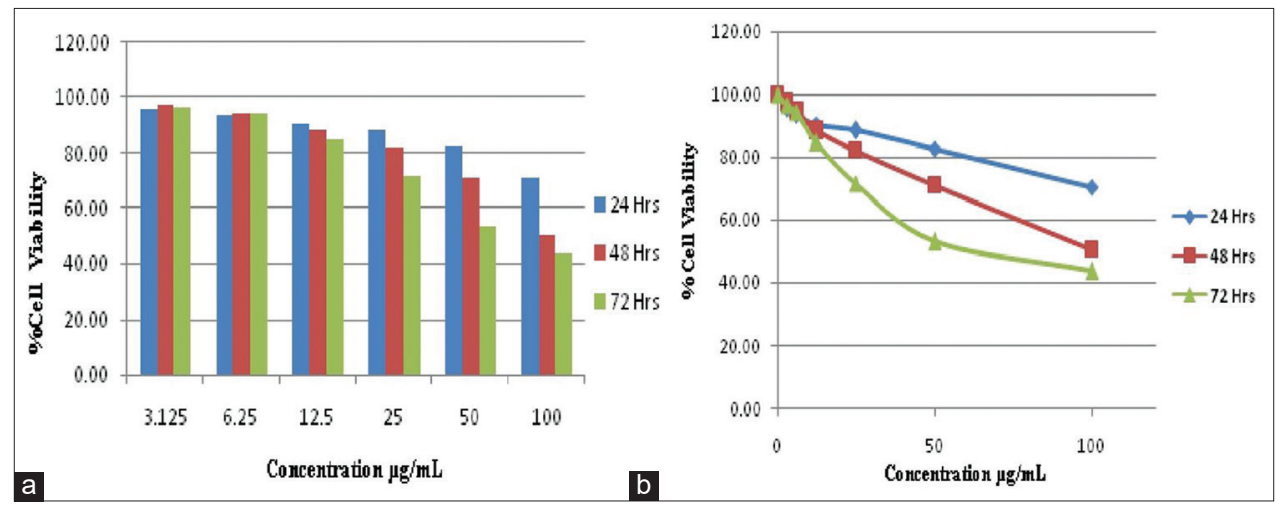

Fig. 1: (a and b) Cytotoxicity of secoisolariciresinol diglucoside on HT-29 cell line

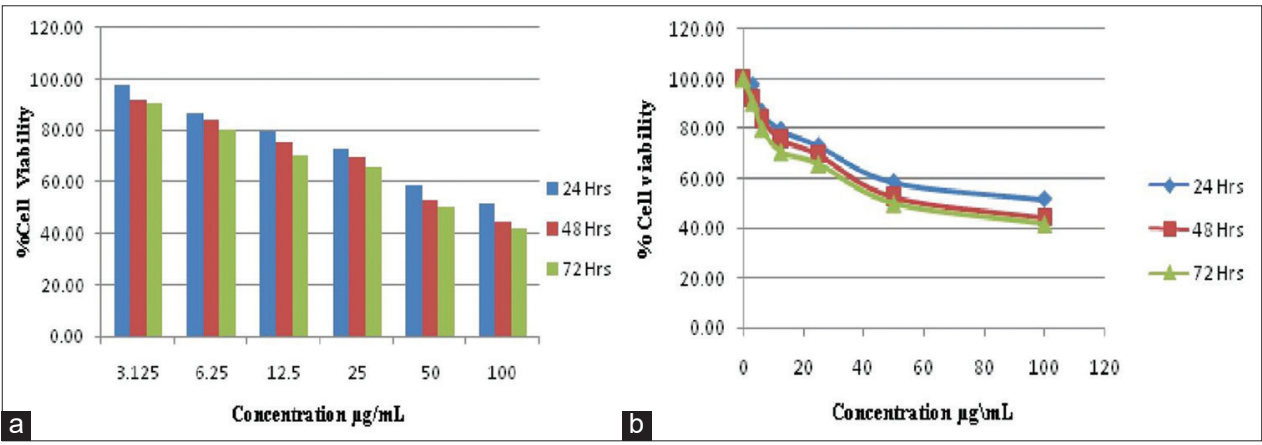

Fig. 2: (a and b) Cytotoxicity of secoisolariciresinol diglucoside on PA-1 cell line 
$100 \mu \mathrm{g} / \mathrm{ml}$ of SDG were added on to the partial monolayer in microtiter plates. The plates were then incubated at $37^{\circ} \mathrm{C}$ for another 3 days in $5 \%$ $\mathrm{CO}_{2}$ atmosphere. Then, $100 \mu \mathrm{L}$ of MTT ( $5 \mathrm{mg} / 10 \mathrm{ml}$ of MTT in PBS) was added to each well. The plates were incubated further for $4 \mathrm{~h}$ at $37^{\circ} \mathrm{C}$ in $5 \% \mathrm{CO}_{2}$ atmosphere [32]. The supernatant was removed and $100 \mu \mathrm{L}$ of DMSO was added and the plates were gently shaken to dissolve the formed formazan. The absorbance was measured at different interval time points of $24 \mathrm{~h}, 48 \mathrm{~h}$, and $72 \mathrm{~h}$ of incubation periods for both the cell lines. The absorbance was measured using Spectrostar Nano ELISA microplate reader at a wavelength of $570 \mathrm{~nm}$ for viable cells. The percentage growth inhibition was calculated and the concentration of SDG needed to inhibit cell growth by $50 \%\left(\mathrm{IC}_{50}\right)$ determined graphically. The absorbance was measured using wells without sample containing cells as blanks.

Table 3: $\alpha$-amylase inhibition activity of SDG

\begin{tabular}{llllll}
\hline Concentration & $\begin{array}{l}\text { Control } \\
\text { Abs }\end{array}$ & $\begin{array}{l}\text { SDG } \\
\text { Abs }\end{array}$ & $\begin{array}{l}\text { Acarbose } \\
\text { Abs }\end{array}$ & \multicolumn{2}{l}{ \% inhibition } \\
\cline { 5 - 6 } & & & & SDG & Acarbose \\
\hline $50 \mu \mathrm{g}$ & 0.184 & 0.192 & 0.263 & 4 & 30 \\
$100 \mu \mathrm{g}$ & & 0.198 & 0.289 & 7 & 36 \\
$250 \mu \mathrm{g}$ & 0.234 & 0.328 & 21 & 44 \\
$500 \mu \mathrm{g}$ & 0.247 & 0.396 & 26 & 54 \\
$1000 \mu \mathrm{g}$ & 0.252 & 0.574 & 27 & 68 \\
$2000 \mu \mathrm{g}$ & 0.279 & 0.862 & 34 & 79 \\
\hline
\end{tabular}

SDG: Secoisolariciresinol diglucoside

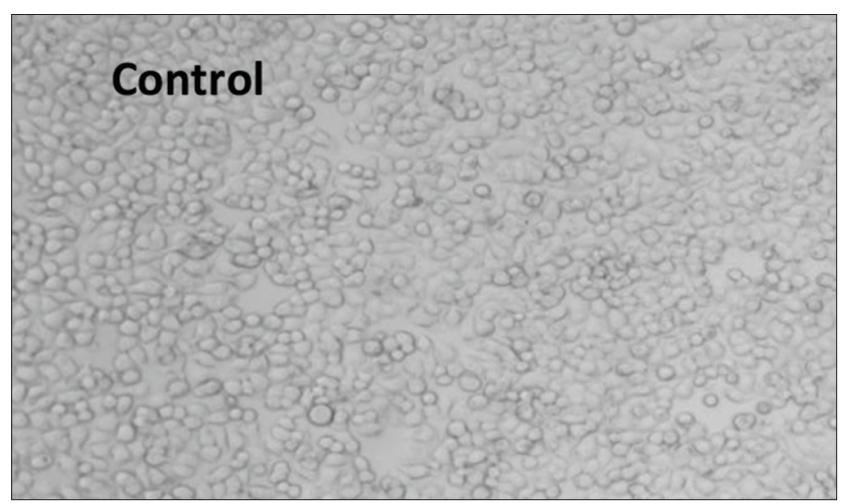

Fig. 3: Morphology of secoisolariciresinol diglucoside-treated HT-29 cells (control)
Preparation of test solutions for cytotoxic study

For $\alpha$-amylase inhibition assay, various concentrations of sample solutions $50 \mu \mathrm{g}, 100 \mu \mathrm{g}, 250 \mu \mathrm{g}, 500 \mu \mathrm{g}, 1000 \mu \mathrm{g}$, and $2000 \mu \mathrm{g}$ were prepared.

\section{$\alpha$-amylase inhibition assay}

The assay was carried out using transformed method of Sudha et al. International Society for Complementary Medicine Research [33]. A $0.1 \mathrm{mg} / \mathrm{ml}$ concentration of $\alpha$-amylase was dissolved in (PBS, $0.02 \mathrm{~mol} / \mathrm{L}, \mathrm{pH}$ 6.8). A $0.25 \mathrm{ml}$ of $\alpha$-amylase solution was added to $0.25 \mathrm{ml}$ of each sample concentration and incubated at $37^{\circ} \mathrm{C}$ for $5 \mathrm{~min}$. The reaction was originated by adding $0.5 \mathrm{ml}$ of $1.0 \%(\mathrm{w} / \mathrm{v})$ starch substrate solution and incubated for $3 \mathrm{~min}$ at $37^{\circ} \mathrm{C}$. The reaction was halted by adding $0.5 \mathrm{ml}$ 3,5-dinitrosalicylic acid (which was prepared by mixing $1 \%$ dinitrosalicylic acid, $0.05 \% \mathrm{Na}_{2} \mathrm{SO}_{3}$, and $1 \%$ $\mathrm{NaOH}$ solution) reagent to the reaction mixture and heated at $100^{\circ} \mathrm{C}$ for $5 \mathrm{~min}$.

\section{RESULTS AND DISCUSSION}

\section{Cytotoxic activity}

The effect of the samples on the proliferation of HT-29 and PA- 1 was expressed as the percentage cell viability, using the following formula:

$\%$ Cell viability $=($ OD of the sample/OD of the Control) $\times 100$

The cytotoxic potential of SDG was examined by MTS assay. The numbers of viable HT-29 and PA-1 cells were decreased after treatment with SDG (Figs. 3-10). Former studies proposed that EL and ED significantly reduced the proliferation of human colon tumor cell lines LS174T, Caco2, HCT-15, and T-84 after incubation with various levels of EL and ED for 8-10 days [34]. A study indicated flaxseed decreases the risk for colon carcinogenesis, the total number of ACs and foci was significantly reduced by $41-53 \%$ and $48-57 \%$, respectively [24]. Another study proven that flaxseed and defatted flaxseed have a colon cancerprotective effect and that this effect is due, in part, to standard deviation (SD) and not the oil at 2.5-5\% levels of intake. The colon cancerprotective effects of flaxseed, defatted flaxseed, and SD are associated with a dose-dependent increase in cecal activity of P-glucuronidase and urinary lignan excretion, however, not to short-chain fatty acids production or $\mathrm{pH}$ [35]. In a 28-day feeding study on carcinogen-treated rats, flaxseed and defatted flaxseed have been shown to significantly reduce epithelial cell proliferation and the number of ACs and ACF which are thought to be early markers of colon cancer risk. The effect of flaxseed at 5 and 10\% levels was not dose related. The study on
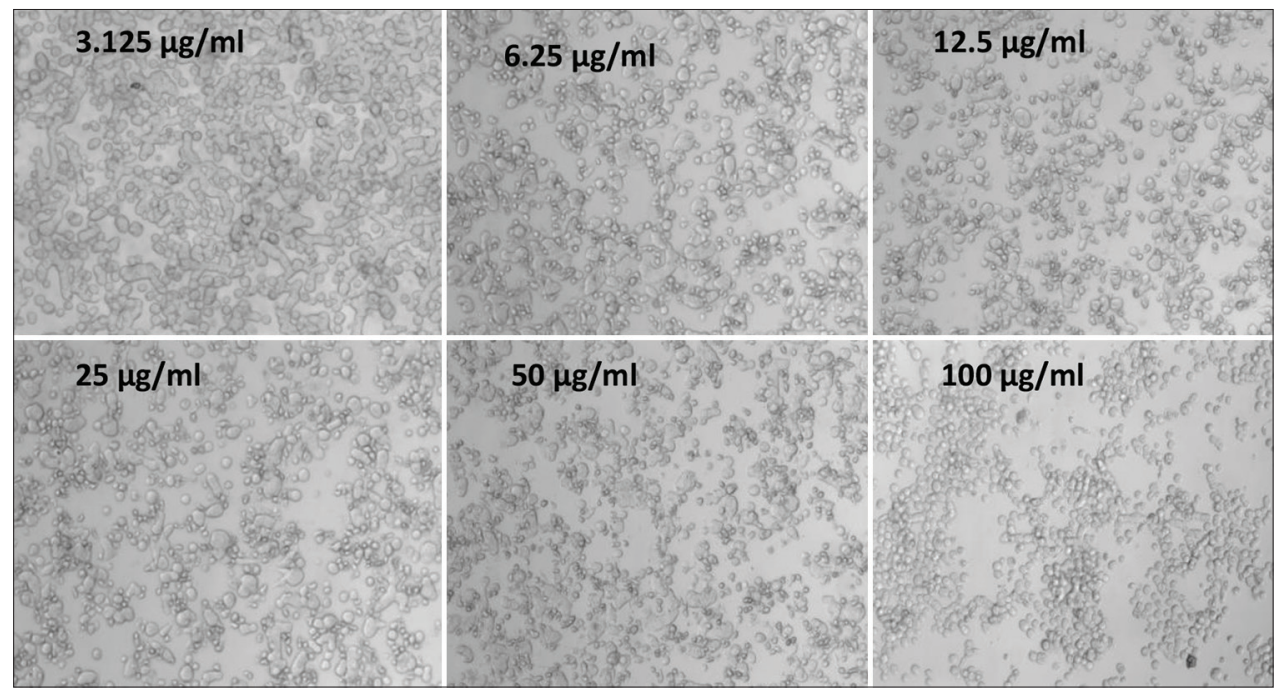

Fig. 4: Morphology of secoisolariciresinol diglucoside-treated HT-29 cells (24 h) 


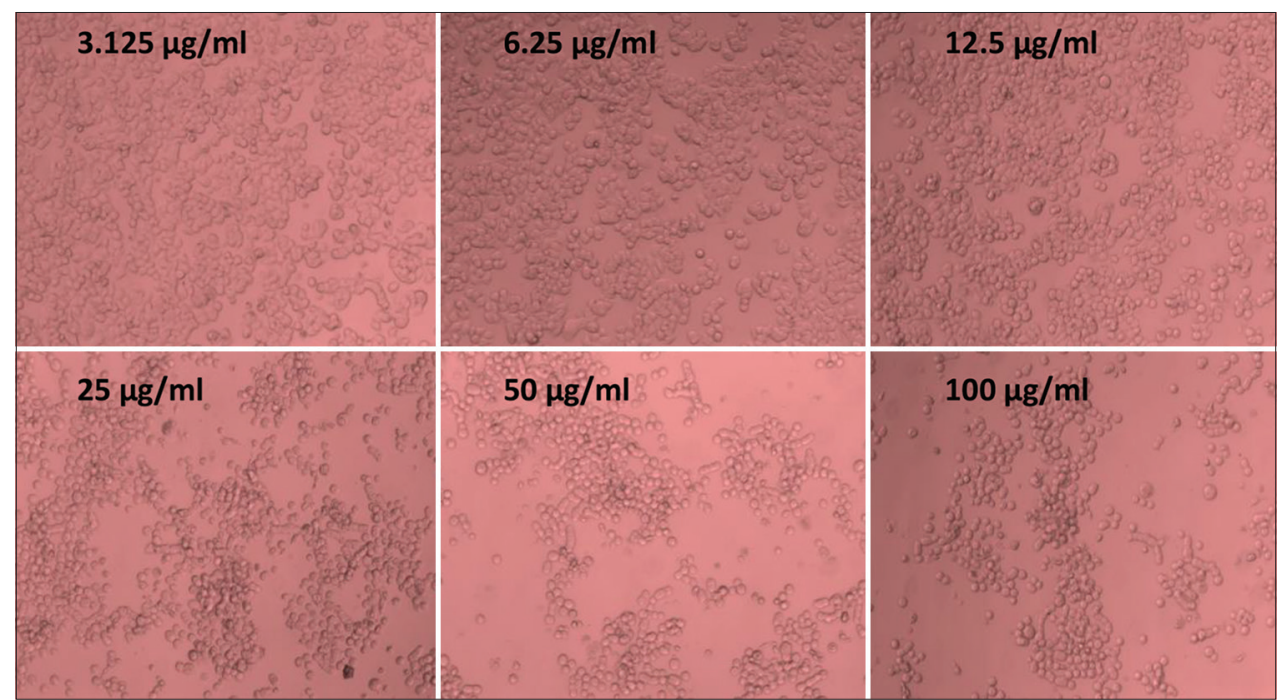

Fig. 5: Morphology of secoisolariciresinol diglucoside-treated HT-29 cells ( $48 \mathrm{~h}$ )

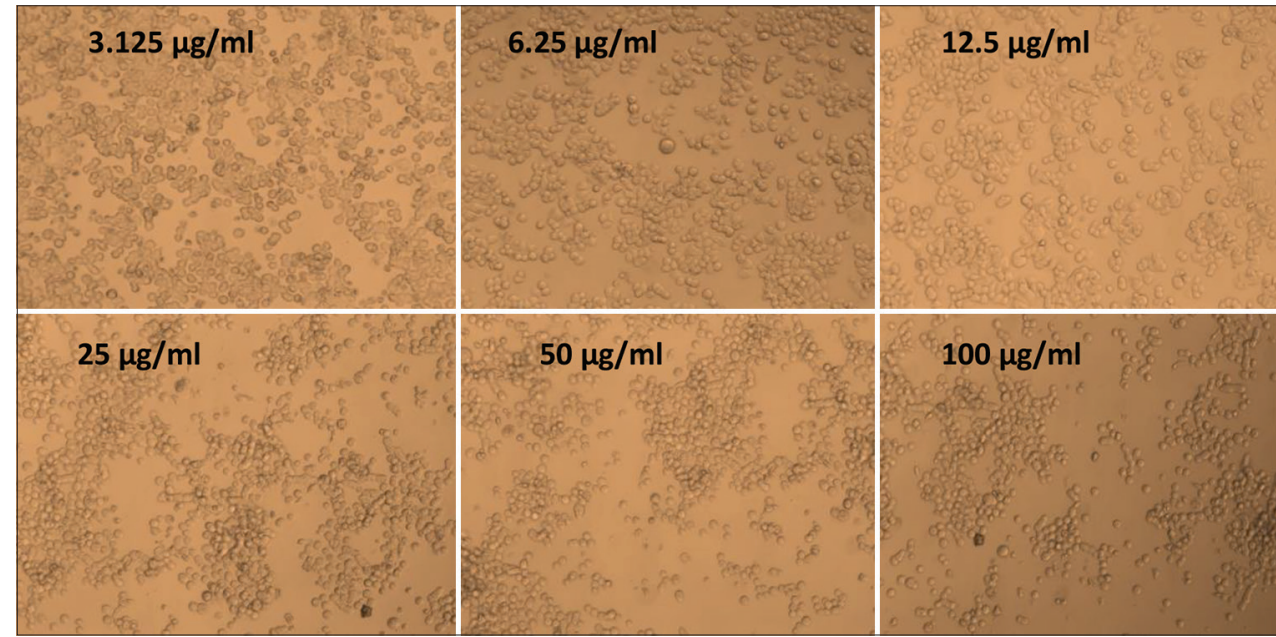

Fig. 6: Morphology of secoisolariciresinol diglucoside-treated HT-29 cells (72 h)

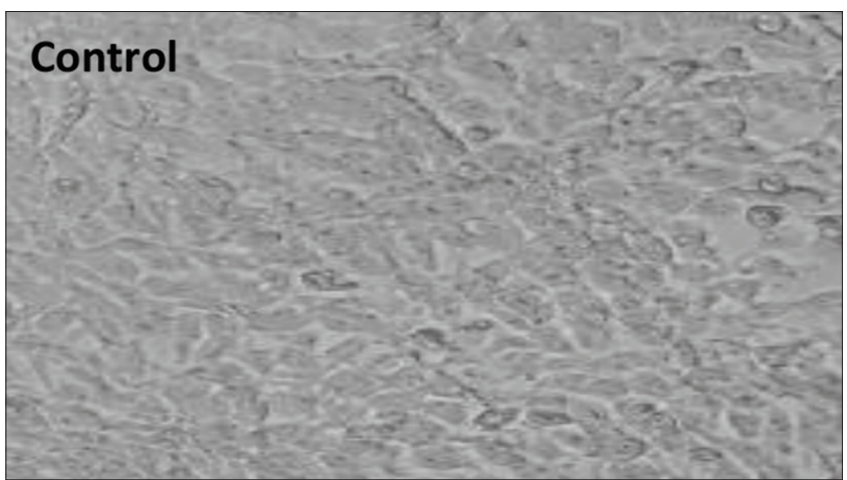

Fig. 7: Morphology of secoisolariciresinol diglucoside-treated PA-1 cells (control)

rye bran, flaxseed, and SDG has been shown to be protective against azoxymethane-induced colon carcinogenesis in rats [24,25].

Unlike the previous studies, the current in vitro study has been carried out only up to $72 \mathrm{~h}$, at lower concentrations of SDG which was isolated from the defatted flaxseed indicated a dose- and time-dependent cytotoxic activity.

$\mathrm{IC}_{50}-\mathrm{A}$ concentration of an inhibitor where the response (or binding) is reduced by half of its maximum. IC $_{50}$ values for the present cytotoxicity studies were derived from a non-linear regression analysis (curve fit) based on sigmoid dose-response curve. The $\mathrm{IC}_{50}$ values of HT-29 cell lines were $>100 \mu \mathrm{g} / \mathrm{ml}$ for $24 \mathrm{~h}, 192.91 \mu \mathrm{g} / \mathrm{ml}$ for $48 \mathrm{~h}$, and for $75.58 \mu \mathrm{g} /$ $\mathrm{ml} 72 \mathrm{~h}$. Whereas for PA-1, the IC $\mathrm{I}_{50}$ values were $112.70 \mu \mathrm{g} / \mathrm{ml}, 72.69 \mu \mathrm{g} /$ $\mathrm{ml}$, and $57.49 \mu \mathrm{g} / \mathrm{ml}$ for $24 \mathrm{~h}, 48 \mathrm{~h}$, and $72 \mathrm{~h}$, respectively.

As shown in Figs. 1 and 2, SDG shows significant concentrationdependent inhibition on propagation and viability of the colon cancer cell line (HT-29) and ovarian cell lines (PA-1). IC $_{50}$ values are summarized in Tables 1 and 2 which are clearly indicating that SDG is proficient to inhibited the growth of two human cancer cell lines, namely, HT-29 and PA-1. Morphology of the SDG-treated HT-29 cells is presented in the consequent, Figs. 3-10.

\section{$\alpha$-amylase inhibition activity}

After cooling the reaction mixture to room temperature, the absorbance was recorded by ELICO, SL-210 spectrophotometer. The absorbance (Abs) recorded at $540 \mathrm{~nm}$ by keeping diluents (PBS) as a control. 


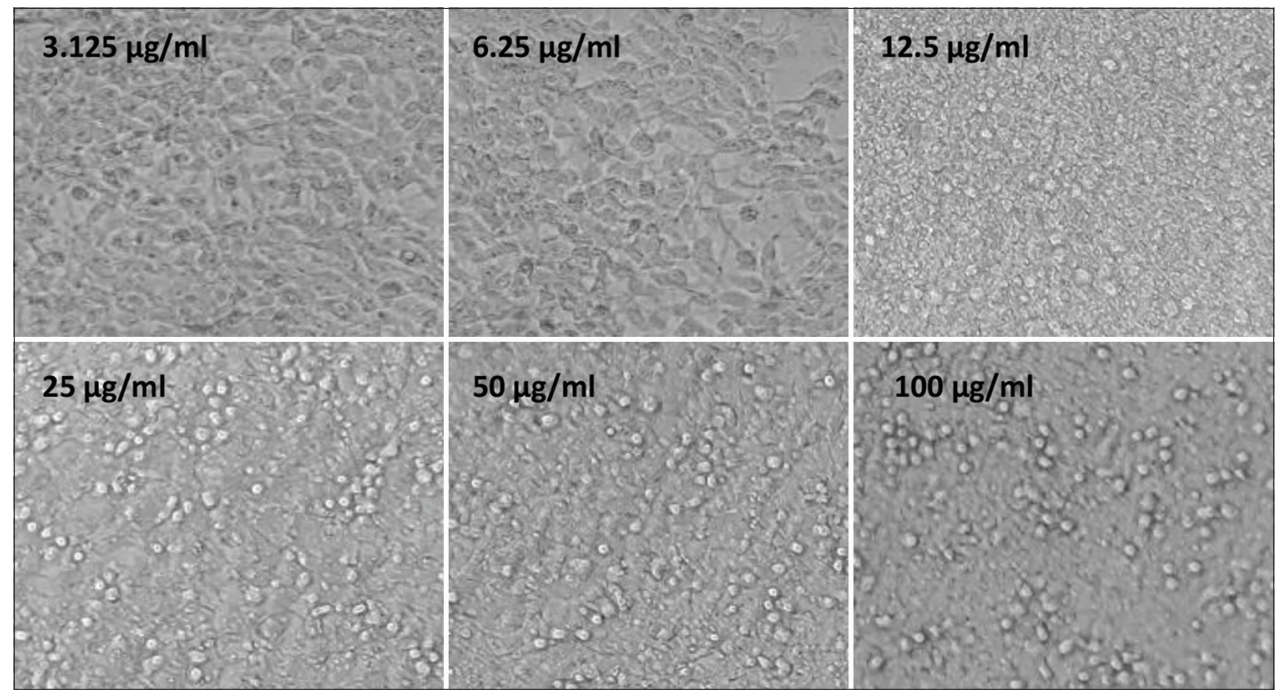

Fig. 8: Morphology of secoisolariciresinol diglucoside-treated PA-1 cells (24 h)

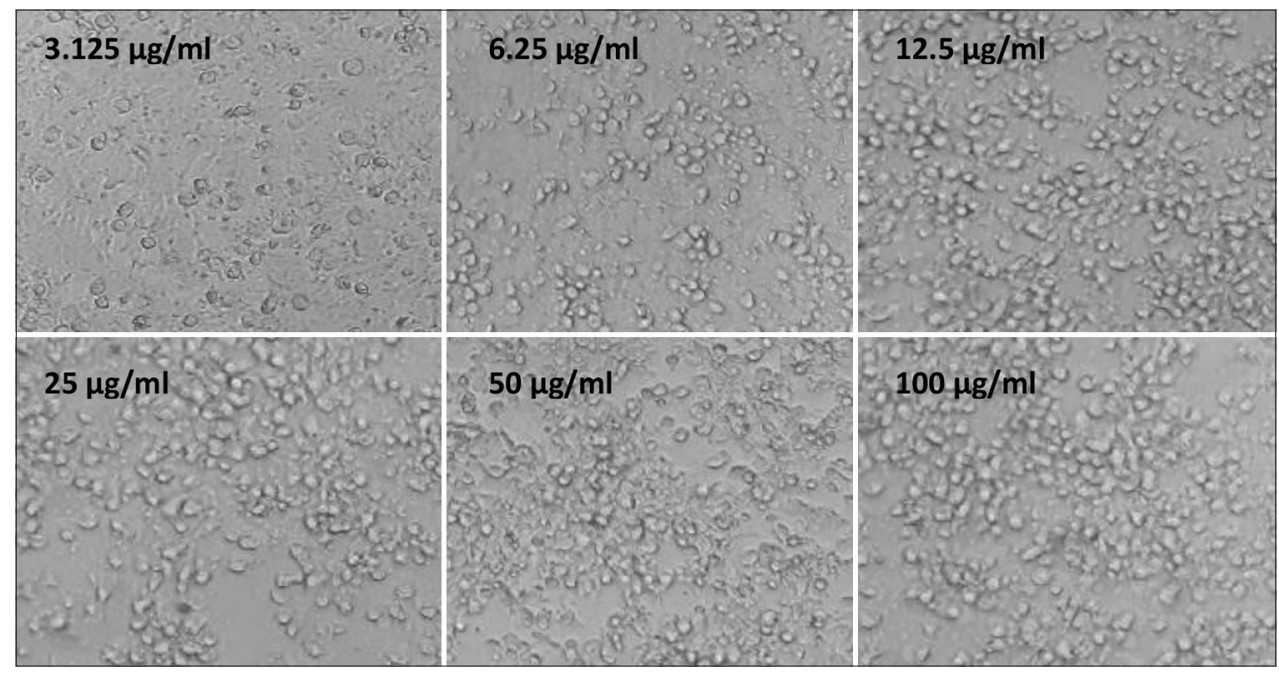

Fig. 9: Morphology of secoisolariciresinol diglucoside-treated PA-1 cells (48 h)

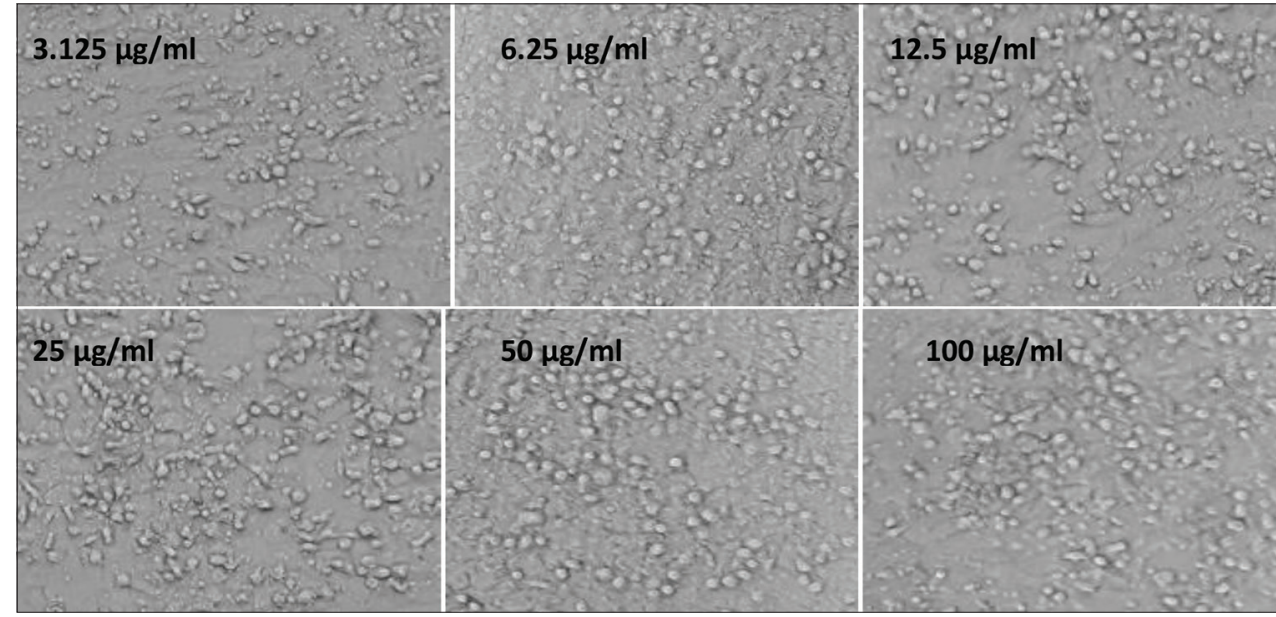

Fig. 10: Morphology of secoisolariciresinol diglucoside-treated PA-1 cells (72 h)

The inhibition percentage was calculated by the following equation:

Inhibition $(\%)=([$ Abs1-Abs2]/Abs1 $) \times 100$ where, Abs1 $=$ sample and Abs2=control.
The previous studies shown $\alpha$-amylase inhibitory potential of flaxseed extracts of isopropanol, acetone, and methyl t-butyl ether [30]. However, the current study demonstrated the $\alpha$-amylase inhibitory of pure SDG which is exhibiting relatively similar inhibition to that of acetone 
fraction $(\approx 30 \%)$ Table 3. SDG has shown to be efficient in preventing or delaying the progress of diabetes mellitus in animal models, which was considered to be attributable to its strong antioxidant activity [36,37]. SDG was also shown to suppress the expression of the phosphoenolpyruvate carboxykinase gene that codes for the ratelimiting enzyme responsible for gluconeogenesis in the liver [38]; these studies have been proved that SDG prevented the development of diabetes.

\section{CONCLUSION}

Based on the above results, it is concluded that SDG isolated from flaxseed exhibited cytotoxic activity against colon and ovarian cancer cells and moderate hyperglycemic activity by inhibiting $\alpha$-amylase. It is showed a considerable dose-dependent inhibition. $\alpha$-amylase inhibitors from plant sources possess natural therapeutic approach to the treatment of postprandial hyperglycemia by decreasing glucose release from starch and delaying carbohydrate absorption in the small intestine and may have potential for use in the treatment of diabetes mellitus and obesity. However, clinical studies need the confirmation of SDG as safe and effective with supporting evidence from human and animal studies for future research.

\section{AUTHORS' CONTRIBUTIONS}

The author declares that this work was done by the author named in this article.

\section{CONFLICTS OF INTEREST}

The authors have declared no conflicts of interest.

\section{FUNDING}

This research did not receive any specific grant from funding agencies.

\section{REFERENCES}

1. Ueda J, Tezuka Y, Banskota AH, Tran Q, Harimaya Y, Saiki I. Anti proliferative activity of Vietnamese medicinal plants. Biol Pharm Bull 2002;25:753-60

2. Dixon N, Wong LS, Geerlings TH, Micklefield J. Cellular targets of natural products. Nat Prod Rep 2007;24:1288-310.

3. Petrovska BB. Historical review of medicinal plants' usage. Pharmacogn Rev 2012;6:1-5.

4. Oran SA, Al-Eisawi DM. Check-list of medicinal plants in Jordan. Dirasat 1998;25:84-112.

5. Jain K. Medicinal plants of India. Raj Bandhu Ind Co 1985;5:1-4.

6. Newman DJ, Cragg GM. Natural products as sources of new drugs over the last 25 years. J Nat Prod 2007;70:461-77.

7. Rates SM. Plants as source of drugs. Toxicon 2001;39:603-13.

8. Graham JG, Quinn ML, Fabricant DS, Farnsworth NR. J Ethnopharmacol 2000;73:347-77.

9. Food and Agriculture Organization. Trade in Medicinal Plants, Economic and Social Department. United Nations, Rome, Italy: Food and Agriculture Organization; 2004.

10. Kuno T, Testuya T, Akira H, Takuji T. Cancer chemoprevention through the induction of apoptosis by natural product. J Biophysical Chem 2012;3:156-73.

11. Wu J, Wu Y, Yang BB. Anticancer activity of Hemsleya amabilis extract. Life Sci 2002;71:2161-70.

12. Kviecinski MR, Felipe KB, Schoenfelder T, de Lemos Wiese LP, Rossi MH, Gonçalez E, et al. Study of the antitumor potential of Bidens pilosa (Asteraceae) used in Brazilian folk medicine. J Ethnopharmacol 2008;117:69-75.

13. Okhti ZA, Al-Ezzi MI, Abdulmahdi R. The protective role of flaxseed lignan in male rabbits with high fat diet: A histopathological study. Int $\mathrm{J}$ Pharm Pharm Sci 2016;8:90-4.
14. Berquin IM, Edwards IJ, Chen YQ. Multi-targeted therapy of cancer by omega-3 fatty acids. Cancer Lett 2008;269:363-77.

15. Czene S, Testa E, Nygren J, Belyaev I, Harms-Ringdahl M. DNA fragmentation and morphological changes in apoptotic human lymphocytes. Biochem Biophys Res Commun 2002;294:872-8.

16. Jayashree T, Kishore KK, Vinay M, Vasavi P, Chandrashekhar N, Manohar VS. Evaluation of the diuretic effect of the chloroform extract of the Benincasa hispida Rind (pericarp) extract in Guinea pigs J Clin Diagn Res 2011;5:578-82.

17. Lewis WH, Elvin-Lewes MP. Medicinal Botany; Plants Affecting Man's Health. New York: John Wiley and Sons; 1997. p. 515.

18. Prabakaran M, Chandrakala N, Selvam AP. Antimicrobial activity of Indigofera glandulosa (wild). Asian J Plant Sci Res 2011;1:18-25.

19. Kurzer MS, Xu X. Dietary phytoestrogens. Annu Rev Nutr 1997;17:353-81.

20. Oroian M, Escriche I. Antioxidants: Characterization, natural sources, extraction and analysis. Food Res Int 2015;74:10-36.

21. Nandi I, Ghosh M. Studies on functional and antioxidant property of dietary fibre extractedfrom defatted sesame husk, rice bran and flaxseed. Bioact Carbohydr Diet Fibre 2015;5:129-36.

22. Alphonse PA, Aluko RE. Anti-carcinogenic and anti-metastatic effects of flax seed lignan secolariciresinol diglucoside (SDG). Discov Phytomed 2015;2:12-7.

23. Thompson LU. Experimental studies on lignans and cancer. Baillieres Clin Endocrinol Metab 1998;12:691-705.

24. Serraino M, Thompson LU. Flaxseed supplementation and early markers of colon carcinogenesis. Cancer Lett 1992;63:159-65.

25. Davies MJ, Bowey EA, Adlercreutz H, Rowland IR, Rumsby PC. Effects of soy or rye supplementation of high-fatdiets on colon tumour development in azoxymethane-treated rats. Carcinogenesis 1999;20:927-31.

26. Bird RP. Observation and quantification of aberrant crypts in the murine colon treated with a colon carcinogen: Preliminary findings. Cancer Lett 1987;37:147-51.

27. Nair SS, Kavrekar V, Mishra A. In vitro studies on alpha amylase and alpha glucosidase inhibitory activities of selected plant extracts. Pelagia Res Libr Eur J Exp Biol 2013;3:128-32.

28. Shailimavardhini RD, Reddinaik BM, Ramesh B. Screening and production of $\alpha$-amylase from Aspergillus niger using zero value material for solid state fermentat ion. Int J Pharm Pharm Sci 2005;5:55-60.

29. Daddala GB, Rani AS, Papineni S. Optimization of simple methodology for extraction, purification of SDG from Linum usitatissimum and its characterization. Curr Trends Biotechnol Pharm 2018;12:267-74.

30. Stockert JC, Blázquez-Castro A, Cañete M, Horobin RW, Villanueva A. MTT assay for cell viability: Intracellular localization of the formazan product is in lipid droplets. Acta Histochem 2012;114:785-96.

31. Saravanan BC, Sreekumar C, Bansal GC, Ray D, Rao JR, Mishra AK. A rapid MTT colorimetric assay to assess the proliferation index of two Indian strains of Theileria annulata. Vet Parasitol 2003;113:211-6.

32. Xiao JB, Chen XQ, Zhang YW, Jiang XY, Xu M. Cytotoxicity of Marchanpia convoluta leaf extracts on human liver and lung cancer cells. Braz J Med Biol Res 2006;39:731-8.

33. Sudha P, Zinjarde SS, Bhargava SY, Kumar AR. Potent $\alpha$-amylase inhibitory activity of Indian Ayurvedic medicinal plants. BMC Complement Altern Med 2011;11:5.

34. Sung MK, Lautens M, Thompson LU. Mammalian lignan inhibit the growth of estrogen independent human colon tumor cells. Anticancer Res 1998;18:1405-8.

35. Jenab M, Thompson LU. The influence of flaxseed and lignans on colon carcinogenesis and beta-glucuronidase activity. Carcinogenesis 1996; $17: 1343-8$

36. Prasad K. Oxidative stress as a mechanism of diabetes in diabetic BB prone rats: Effect of secoisolariciresinol diglucoside (SDG). Mol Cell Biochem 2000;209:89-96.

37. Prasad K. Secoisolariciresinol diglucoside from flaxseed delays the development of Type 2 diabetes in Zucker rat. J Lab Clin Med 2001;138:32-9.

38. Prasad K. Suppression of phosphoenolpyruvate carboxykinase gene expression by secoisolariciresinol diglucoside (SDG), a new antidiabetic agent. Int J Angiol 2002;11:107-9. 